\title{
Malnutrition among Children under 5 Does Not Correlate with Higher Socio Economic Status of Parents in Rural Communities
}

\author{
Ahmad Isah Muhammad1 ${ }^{*}$, Isa Yunusa1, Mohammed Tahiru Bolori², \\ Lawrence Uchenna Sunday Ezeanyika ${ }^{3}$, Hamisu Abdullahi Walla ${ }^{4}$, Zulaihat Mukhtar Gidado ${ }^{5}$ \\ ${ }^{1}$ Department of Biochemistry, Kano University of Science and Technology, Wudil, Nigeria \\ ${ }^{2}$ Department of Community Medicine, University of Maiduguri, Maiduguri, Nigeria \\ ${ }^{3}$ Department of Biochemistry, University of Nigeria, Nsukka, Nigeria \\ ${ }^{4}$ Country Office, World Health Organisations, Abuja, Nigeria \\ ${ }^{5}$ Department of Science Laboratory Technology, School of Technology, Kano State Polytechnic, Kano, Nigeria \\ Email: *ahmadsyahd@gmail.com
}

How to cite this paper: Muhammad, A.I., Yunusa, I., Bolori, M.T., Ezeanyika, L.U.S., Walla, H.A. and Gidado, Z.M. (2017) Malnutrition among Children under 5 Does Not Correlate with Higher Socio Economic Status of Parents in Rural Communities. Open Access Library Journal, 4: e3906. https://doi.org/10.4236/oalib.1103906

Received: August 24, 2017

Accepted: September 24, 2017

Published: September 27, 2017

Copyright $\odot 2017$ by authors and Open Access Library Inc.

This work is licensed under the Creative Commons Attribution International License (CC BY 4.0).

http://creativecommons.org/licenses/by/4.0/

\begin{abstract}
Introduction: Understanding the socioeconomic characteristics of families with undernourished children is very critical to providing solution to the menace especially in rural communities where there is complexity in the relationship between economic activities, education and parental care and the undernutrition. Objectives: The study is aimed at understanding the nutritional status of children under the age of 5 years in relation to the socio economic status of the family so as to determine causes of vulnerability. Methods: Hospital based cross sectional study was carried among 505 children under the age of 5 years, taking measurement of their Mid Upper Arm Circumference (MUAC) using standard techniques and also taking records of their families' socioeconomic data using structured questionnaire. Results: Record of nutritional status of the children sampled shows that undernourished children were 345 (68.3\%) and the nourished were 160 (31.7\%). The number of times each child felt sick within the last one year shows that out of the total 505 children, $140(27.72 \%)$ fell sick once, 155 (30.69\%) fall sick twice in the previous year, 65 (12.87\%) felt sick three times, 55 (10.89\%) felt sick four times due to either malaria, undernutrition or other factors. Children born to farmers, constituting $51.5 \%$ of the sampled children have as high as $69.2 \%$ prevalence of undernutrition, compared to those born to beggars (0\%). The highest prevalence is recorded in children born to petty traders $(80 \%)$, followed by government workers and commercial motorcyclist with $75 \%$ each. Prevalence of $100 \%$ was recorded in the sampled children whose father attains tertiary level of education, followed by those who attain only secondary level of education (68\%). Conclu-
\end{abstract}


sion: There is high prevalence of undernutrition among children in rural communities which is often underestimated for the fact that rural dwellers of Kano are mostly farmers and that they are adequate to provide for their children. Frequency of illnesses among the children of rural dwellers is associated with the nutritional status of the children. Malnutrition is not always dependent on the occupation and educational status of the parents or whether child parents are alive or not. Children of farmers and learned persons are also very susceptible to malnutrition in the rural communities of Kano. Nutritional education and programs should as well target all families with varied socioeconomic status, including farmers, petty traders and those with high educational status without making assumptions that they are less susceptible to malnutrition.

\section{Subject Areas}

Nutrition, Public Health

\section{Keywords}

Malnutrition, Socio-Economic, MUAC, Under 5 Children, Kano

\section{Introduction}

The term malnutrition generally refers to both under nutrition and over nutrition [1]. Malnutrition is frequently part of a vicious cycle that includes poverty and disease. These three factors are interlinked in such a way that each contributes to the presence and permanence of the others. Socioeconomic and political changes that improve health and nutrition can break the cycle; as can be specific nutrition and health interventions [2]. Inadequate diet and disease, in turn, are closely linked to the general standard of living, the environmental conditions, and whether a population is able to meet its basic needs such as food, housing and health care [1]. The World Food Programme (WFP) defines malnutrition as "a state in which the physical function of an individual is impaired to the point where he or she can no longer maintain adequate bodily performance process such as growth, pregnancy, lactation, physical work and resisting and recovering from disease" [3]. Malnutrition is estimated to contribute to more than one third of all child deaths, although it is rarely listed as the direct cause [3] (WFP, 2000).

The impact of malnutrition usually falls mainly on children under five years of age [3]. Contributing to more than half of deaths in children worldwide, child malnutrition was associated with $54 \%$ of deaths in children in developing countries in 2001 [4] [5]. Food security is said to exist if at all times, people have a physical and economic access to sufficient, safe and nutritious food that meet their dietary and food preferences, for an active and healthy life [3]. Certain groups are particularly vulnerable to food insecurity, including women (especially low income pregnant and lactating women), victims of conflict, the ill, mi- 
grant workers, low income urban dwellers, the elderly, and children under five [6]. The establishment of properly functioning economic and political structures would help to lead countries to food security, as well as help to improve the overall wellbeing of the people [7].

The 2015 National Nutrition and Health Survey (NNHS) results seem consistent with the GNR 2015 positive findings, as the overall NNHS 2015 global acute malnutrition (GAM) and severe acute malnutrition (SAM) prevalence for under-five children is reported at 7.2 and 1.8 percent respectively, whereas the same indicators were reported at 8.7 and 2.2 [8]. In addition, none of the states surveyed this year reported GAM and SAM above critical WHO cut off points and there has also been a slight reduction in the underweight indicator (19.4 percent compared to 21 percent in 2014).

Nationally, the likelihood of a child being under weight is 3.5 times higher for children in the poorest households (bottom $20 \%$ of households) than children in the richest households (top 20\% of households) [9]. Malnutrition disproportionately affects poor households since the poorest families spend the greatest proportion of their income on buying staple foods, making them highly vulnerable to price fluctuations [9]. The burden of malnutrition has been directly linked to poverty, quality of food intake, excessive disease and poor health status [10]. Nearly one of every four human beings alive today exists only on the margins of survival, too poor to obtain the food they need to work, or adequate shelter, or minimal health care, let alone education for their children [11].

Poverty is unmistakably the driving factor in the lack of resources to purchase or otherwise procure food, but the root causes of poverty are multifaceted. Poverty, combined with other socioeconomic and political problems, create the bulk of food insecurity around the globe [6]. Improving the educational status of parents, especially of mothers, on nutrition, sanitation and common disease prevention strategies should logically reduce the malnutrition related mortality and morbidity [12]. This problem is very crucial in Sub Saharan Africa, where access to formal education for the girl child in certain communities is still a major burning challenge [12]. This study is aimed at understanding the socio-demographic characteristics of families in relation to their nutritional status of their children under the age of 5 years so as to determine vulnerability to malnutrition per parents' status.

\section{Materials and Methods}

\subsection{Study Area}

Kano State is located in the North Central part of the country between longitude $8.500^{\circ} \mathrm{E}$ and latitude $11.500^{\circ} \mathrm{N}$; it occupies a total surface area of $20,131 \mathrm{~km}^{2}$ $\left(77,773 \mathrm{~m}^{2}\right)$ and has a total population of approximately 11 million. Kano State is a commercial and agricultural region known for the production of groundnuts and cotton. It is also the second largest industrial center in Nigeria, with textile, tanning, footwear, cosmetics, plastic, and other industries. The state consists pri- 
marily of Sudan savannah type vegetation, with an annual mean rainfall of 800 $900 \mathrm{~mm}$, a temperature that ranges between $25^{\circ} \mathrm{C}-40^{\circ} \mathrm{C}$ (mean approximately $26^{\circ} \mathrm{C}$ ), and a relative humidity of $47.43 \%$. The climate of the study area is a tropical dry-and-wet season type typical of West African savannah. The wet season lasts from May to October, while the dry season extends from November to April [13]. In collaboration with primary healthcare personnel and traditional rulers in each local government area (Bichi and Tsanyawa), one ward each was selected randomly. The wards are Badume $\left(8.291^{\circ} \mathrm{E}, 12.201^{\circ} \mathrm{N}\right)$ in Bichi and $\mathrm{Gu}-$ run $\left(7.975^{\circ} \mathrm{E}, 12.343^{\circ} \mathrm{N}\right)$ in Tsanyawa LGA.

\subsection{Study Design}

This is a hospital based cross sectional study to determine relationship between nutritional status and the sociodemographic characteristics such as child school status, parents' educational status, occupation, etc in Bichi and Tsanyawa Kano State between February and December, 2016. Children under the age of 5 years that have given their consent and met the inclusion criteria were selected randomly. MUAC measurement and socio-demographic variables such as age, gender, mother alive, father alive, educational status of parent/guardian, social class, child's educational status and occupation of parent/guardian were noted and recorded into an investigator administered questionnaire.

\subsection{Inclusion Criteria}

1) All consenting children of age of 0 to 59 months who present to their records for the sake of the research.

2) All consenting healthy and unhealthy children matched for age, and other socio-demographical records also included.

\subsection{Exclusion Criteria}

1) Parents who declined consent.

2) Parents who are not willing to take part in the research.

3) Children under no parental or guardian care.

\subsection{Sampling Method}

Systematic random sampling method was used to recruit participants until the desired sample size was obtained. A total of 505 children were selected for the research

\subsection{Sample Size Calculation}

For the calculation of sample size, the following formulae would be used:

$$
\text { Sample size }(n)=\frac{Z_{1-\alpha / 2}^{2} P(1-P)}{d^{2}}
$$

where $Z_{1-\alpha / 2}=$ standard normal variate (At $5 \%$ i.e. $P<0.05=1.96$ ),

$P=$ Expected proportion based on previous studies, 
$d=$ Absolute error or precision allowable by the researcher (5\%) [14]. In order to make up for attrition, an anticipated $90 \%$ (0.9) response is used [15]. Based on this, the "n" was divided by $0.9(n / 0.9)$.

\subsection{Ethical Considerations}

Ethical approval for the study protocol was obtained from the Research and Ethics Committee of Kano State's Ministry of Health. When seeking consent from the volunteers in each facility, the objectives and procedures of the study were explained clearly to them in the local language, Hausa. Participants were also informed that they could withdraw from the study at any time without consequences. Thus, written and signed or thumb-printed informed consents were obtained from all adult participants and guardians/parents on behalf of their children before starting the survey; the ethics committees approved these procedures as well. All malaria-positive individuals were treated with the standard medication according to national malaria drug policy

\subsection{Measurement of Mid Upper Arm Circumference}

Mid Upper Arm Circumference (MUAC) was measured using plastic tape using standard technique [16]. Values obtained as below $11.5 \mathrm{~cm}^{3}$ were considered undernourished [17].

\section{Statistical Analysis}

Data recorded on the questionnaire was transferred to a proforma (in excel format) developed on and then analyzed using the statistical package for social science SPSS V 20.0 (2010) Inc., IBM, New York, USA). Frequency and percentage analysis were done for the categorical variables. Data was presented in frequency charts, descriptive and analytical tables. Bar and pie charts was used to illustrate the results obtained from the participants. Association between studied variables was compared using Chi-Square $\left(\chi^{2}\right)$ and Fisher's exact tests while $P$-value $<0.05$ was considered significant at $95.0 \%$ confidence level. Logistic regression analysis was used to generate odds ratio to assess contribution of the various independent variables such as low educational level, parent alive (both mother and father), employment status of parent, educational status of child was taken.

\section{Limitation}

This is hospital based study and children of the enlightened family are more likely to attend clinics when sick. There can be a lot more susceptible children in the communities who have not been attending clinics and therefore that category may not be represented in this study.

\section{Results}

Socio-demographic characteristics of the study participants were collected from 
five hundred and five (505) participants who took part in the study. The age range is widely distributed amongst the children. Their age ranges from eight months to 59 months, the mean age 30.39 months. There were 260 (51.5\%) males and 245 (48.5\%) females sampled (Figure 1). Children who had their father alive are the most predominant constituting up to $410(81.2 \%)$ followed by children who lost their father with 95 (18.8\%) (Figure 2). Also children who responded mother alive were also predominant with $450(89.1 \%)$ where as children sampled without mother alive constitute $55(10.9 \%)$ respectively (Figure 3$)$. The occupational prestige of the parents counts those who responded none of the options were 110 (21.8\%), whereas farmers making up 260 (51.5\%) about the half of the samples taken, those responded Petty traders connotes 50 (9.9\%), Beggars makes only $15(3 \%)$ of the respondent, commercial motorist makes $15(3 \%)$, commercial cyclist were $20(4 \%)$, company workers makes $20(4 \%)$. moreover, those responded laborers takes the remaining $15(3 \%)$ of the sample (Figure 4). The highest educational level of the parent (father) were taken from none to tertiary level where parents who never attended any formal or semi-formal school

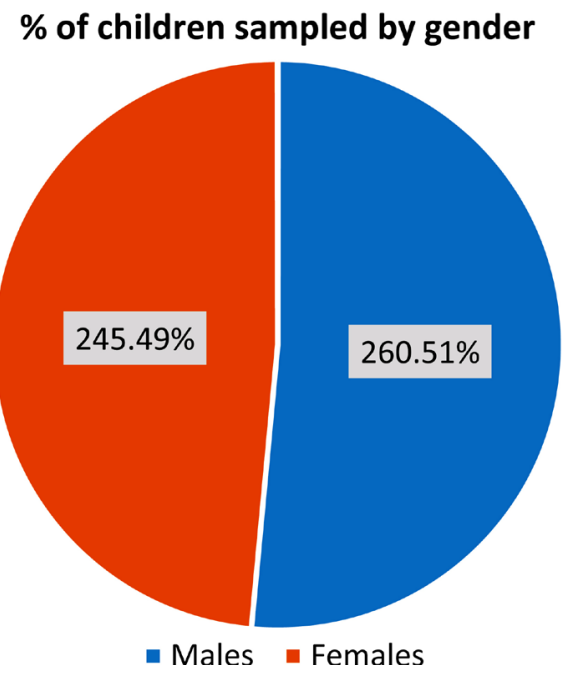

Figure 1. Percentage of children sampled by gender.

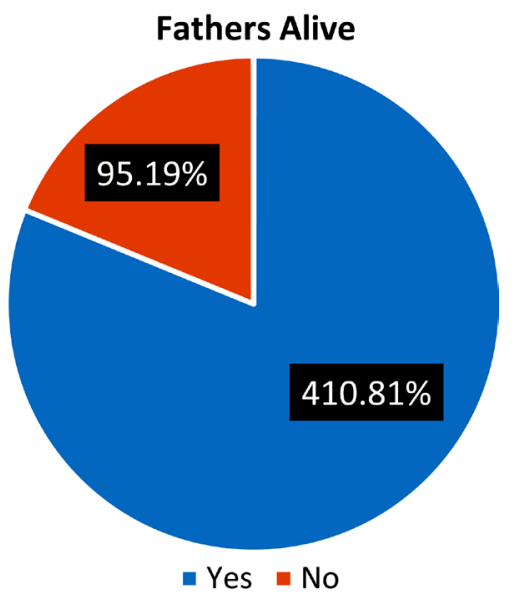

Figure 2. Percentage of children with father alive. 


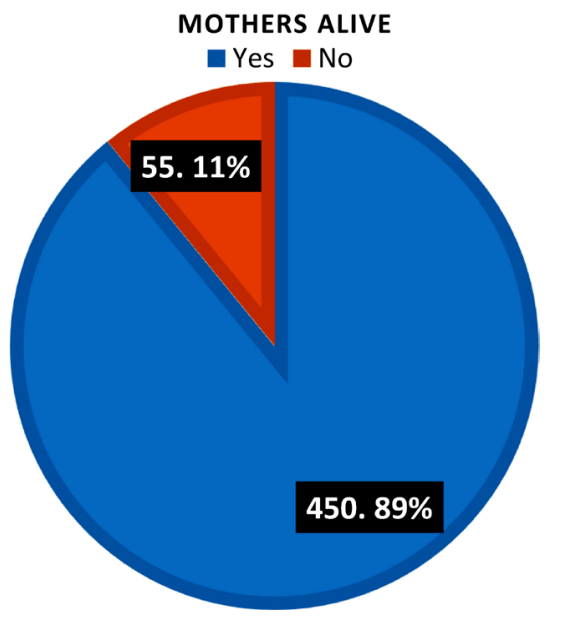

Figure 3. Percentage of children sampled with mother alive.

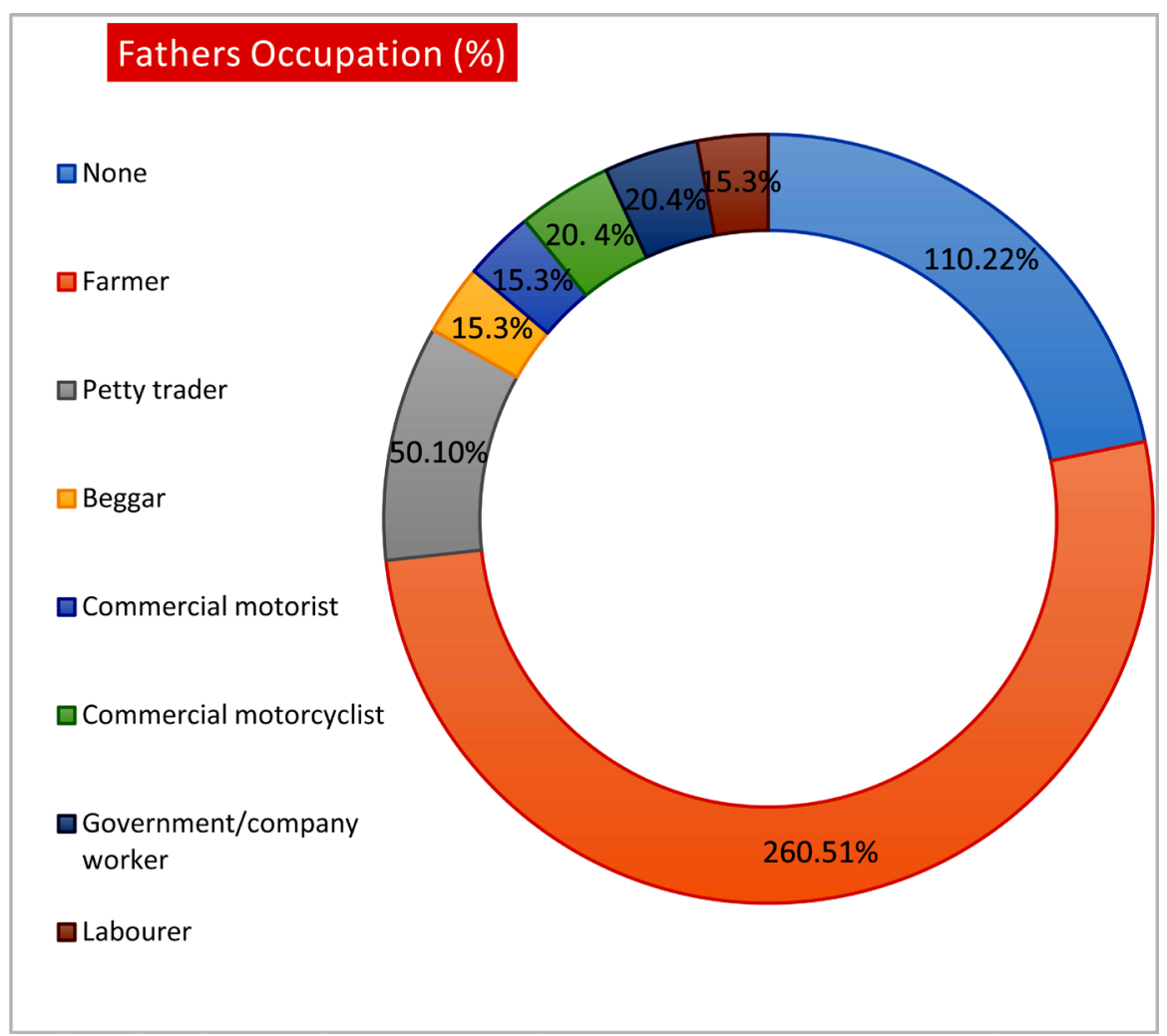

Figure 4. Occupation of children fathers sampled.

(none) makes $40(7.9 \%)$, literacy classes $85(16.8 \%)$, primary 235 (46.5\%) constituting the highest counts in the respondent, secondary 125 (24.8\%), while tertiary education completes $20(4 \%)$ making the lowest counts in the data recorded (Figure 5).

The educational status of the children was taken as schooling and non-schooling where children schooling makes 135 (26.7\%) where the non-schooling makes 370 (73.3\%) (Figure 6). Nutritional status of the children sampled were also recorded (MUAC) where the undernourished makes 345 (68.3\%) and the nou- 
rished were 160 (31.7\%) (Figure 7).

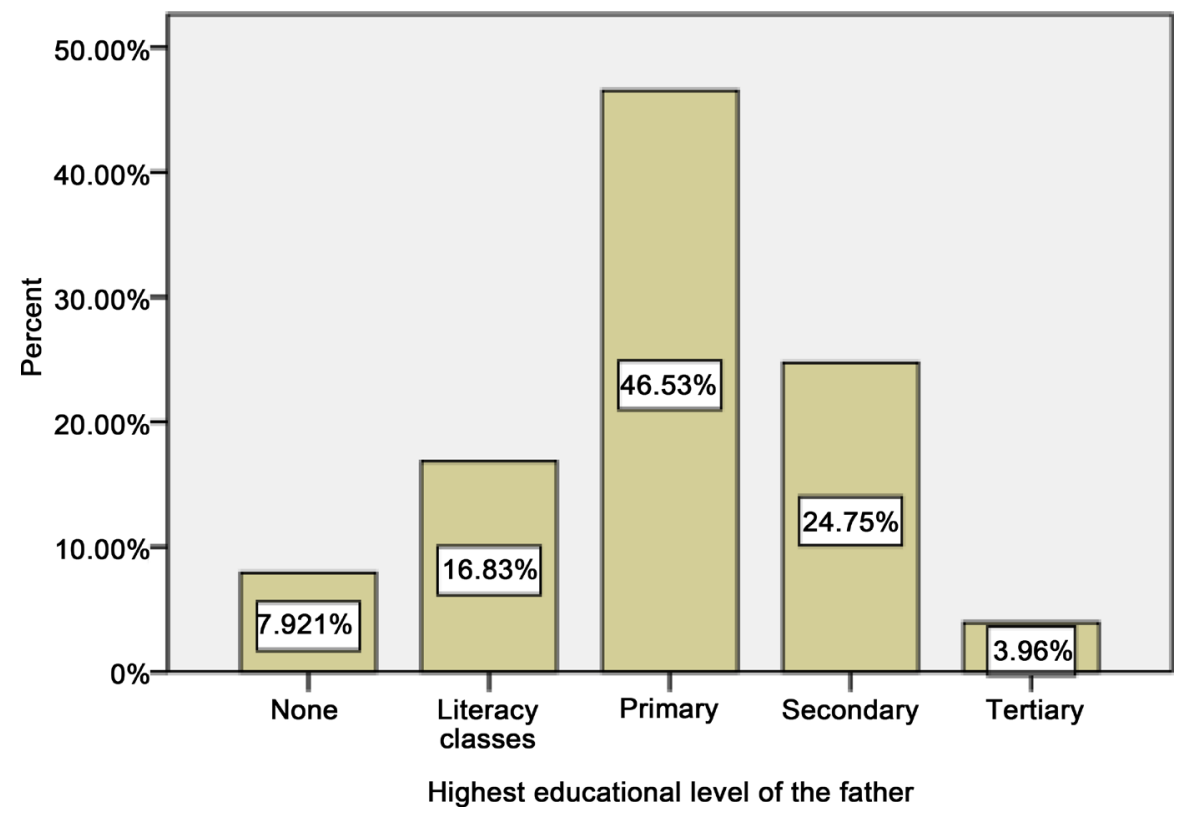

Figure 5. Highest educational level of children fathers.

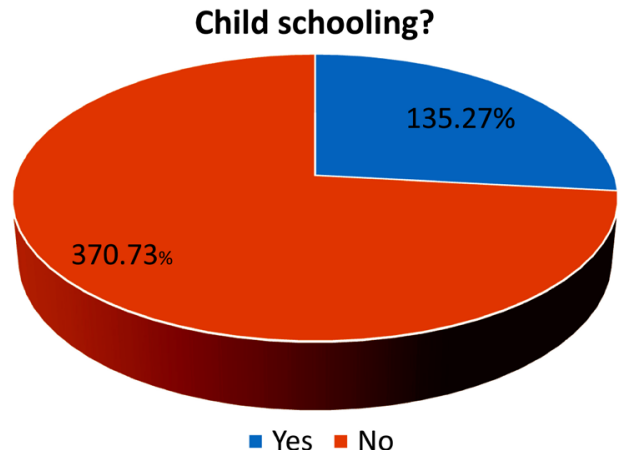

Figure 6. Percentage of children schooling and not schooling.

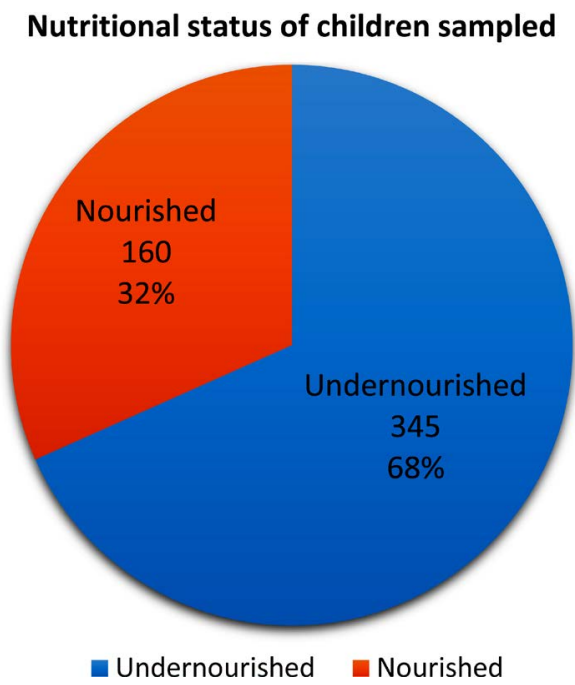

Figure 7. Nutritional status of children sampled. 


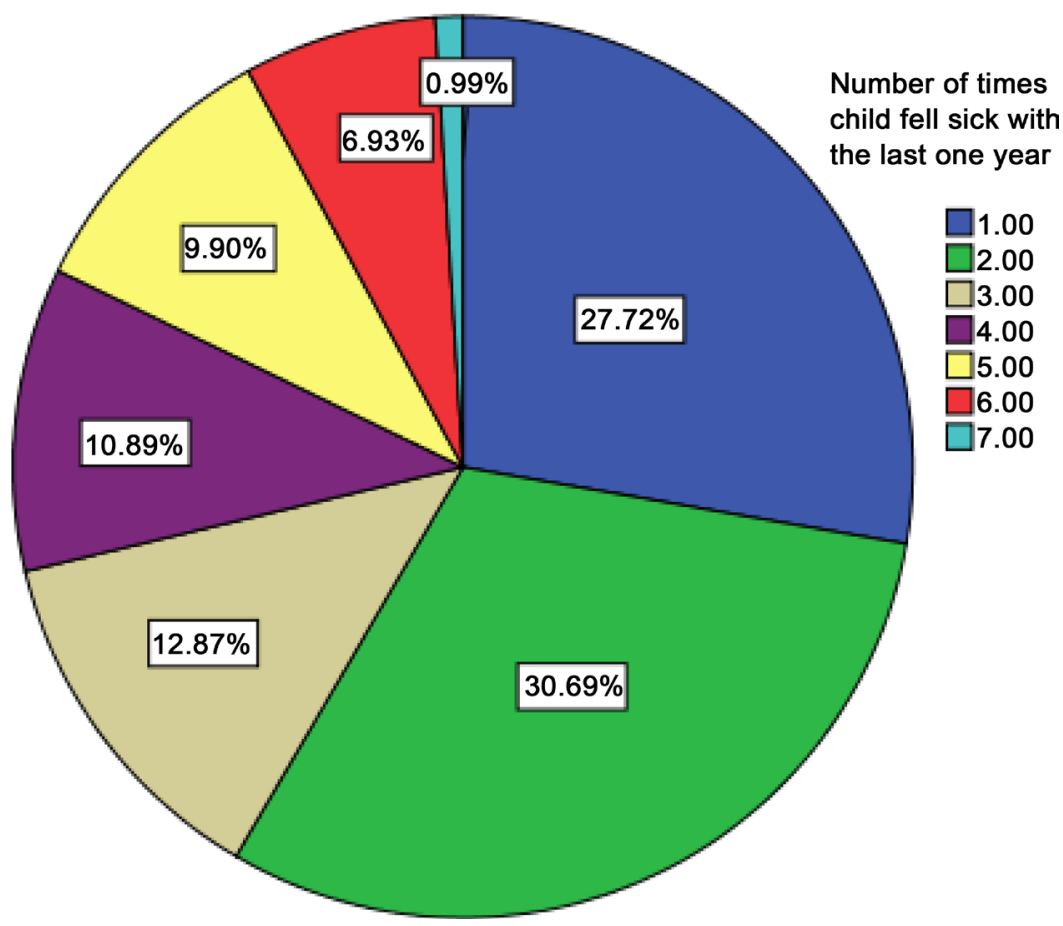

Figure 8. Number of times child within the last one year fell sick.

The number of times each child felt sick within the last one year shows that out of the total 505 children, $140(27.72 \%)$ fall sick once, 155 (30.69\%) fall sick twice in the previous year, 65 (12.87\%) fall sick three times, 55 (10.89\%) fall sick four times due to either malaria, malnutrition or others factors (Figure 8).

The below table shows some of the socio-demographic results in count and percentage of the data.

Table 1 shows the cross tabulation of occupation in relation to nutritional status, eight (8) group of occupation were involve in the study none, farmer, petty trader, Beggar, commercial motorist, commercial motorcyclist and Government/company worker. The first group represents 110 none. About 75 (68.2\%) out of 110 are undernourished and $35(31.8 \%)$ are nourished. The second group represents 260 with $180(69.2 \%)$ are undernourished and 80 (30.8\%) are nourished. The third group represent 50 petty traders with $40(80 \%)$ are undernourished and $10(20 \%)$ are nourished. The fourth represents 15 Beggar which indicate all are nourished. The fifth represent 15 commercial motorists with 10 (66.7\%) are undernourished and 5 (33.3\%) are nourished. The sixth represent 20 commercial motorcyclists with 15 (75\%) are regarded undernourished and 5 (25\%) are nourished. The seventh represent 20 Government/company with 15 (75\%) are undernourished and $5(25 \%)$ are nourished. The last group represent 25 laborers with $10(66.7 \%)$ are undernourished and $5(33.3 \%)$ are nourished. Furthermore, with respect to occupation, most occupation 345 (68.3\%) out of 505 are undernourished and only 160 (31.7\%) are nourished.

Table 2 shows the Pearson chi-square test which is used to test the relationship association between nutritional status and occupation as predictor variable. 
Table 1. Occupation * nutritional status cross tabulation.

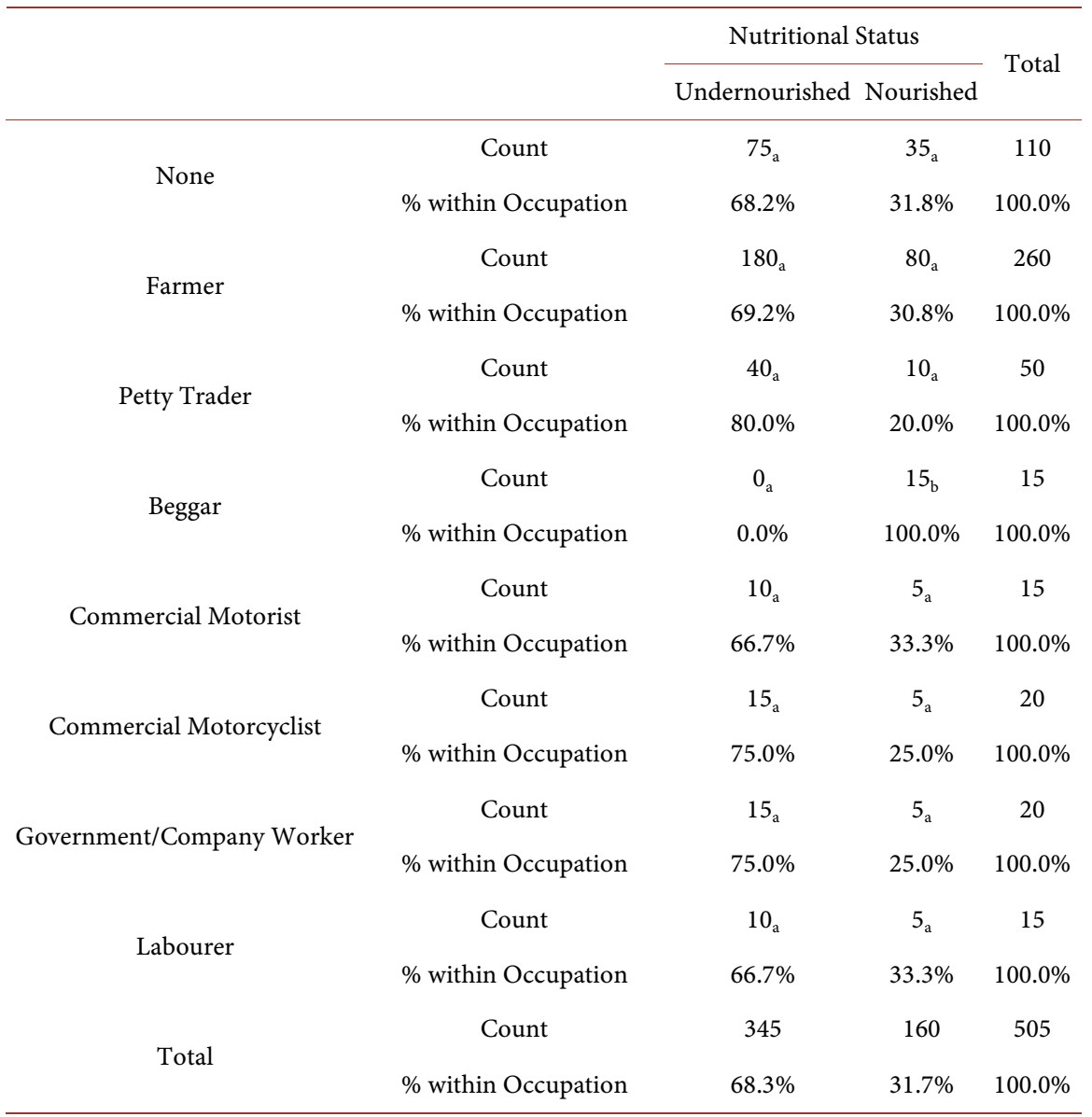

Each subscript letter denotes a subset of Nutritional Status categories whose column proportions do not differ significantly from each other at the 0.05 level.

Table 2. Chi-square tests.

\begin{tabular}{cccc}
\hline & Value & df & Asymp. Sig. (2-Sided) \\
\hline Pearson Chi-Square & $36.461^{\mathrm{a}}$ & 7 & 0.000 \\
N of Valid Cases & 505 & & \\
\hline
\end{tabular}

a. 3 cells $(18.8 \%)$ have expected count less than 5 . The minimum expected count is 4.75 .

Chi-square ( $\left.\chi^{2}=36.461, P<0.005\right)$ shows to be significant among the occupation.

Table 3 shows the cross tabulation of educational level in relation to nutritional status, five (5) group of educational level were involve in the study none, literacy class, primary secondary and tertiary. The first group represents 40 none educated with both $20(50 \%)$ are undernourish and nourished. The second group represents 85 literacy classes with 60 (60.6\%) are undernourish and 25 (29.4\%) are nourished. The third group represents 235 primaries with $150(63.8 \%)$ are undernourished and 85 (36.2\%) are nourished. The fourth represent 125 secondary with $95(76 \%)$ are undernourished and $30(24 \%)$ are nourished. The fifth represent 20 tertiaries with all $20(100 \%)$ are undernourished. Furthermore, with 
Table 3. Highest educational level of the father ${ }^{\star}$ nutritional status cross tabulation.

\begin{tabular}{|c|c|c|c|c|}
\hline & & Nutritional & atus & \\
\hline & & Undernourished & Nourished & \\
\hline & Count & $20_{a}$ & $20_{\mathrm{b}}$ & 40 \\
\hline None & $\begin{array}{c}\text { \% within Highest Educational } \\
\text { Level of the Father }\end{array}$ & $50.0 \%$ & $50.0 \%$ & $100.0 \%$ \\
\hline & Count & $60_{a}$ & $25_{\mathrm{a}}$ & 85 \\
\hline Literacy Classes & $\begin{array}{c}\% \text { within Highest Educational } \\
\text { Level of the Father }\end{array}$ & $70.6 \%$ & $29.4 \%$ & $100.0 \%$ \\
\hline & Count & $150_{\mathrm{a}}$ & $85_{\mathrm{b}}$ & 235 \\
\hline Primary & $\begin{array}{c}\text { \% within Highest Educational } \\
\text { Level of the Father }\end{array}$ & $63.8 \%$ & $36.2 \%$ & $100.0 \%$ \\
\hline & Count & $95_{a}$ & $30_{b}$ & 125 \\
\hline Secondary & $\begin{array}{c}\% \text { within Highest Educational } \\
\text { Level of the Father }\end{array}$ & $76.0 \%$ & $24.0 \%$ & $100.0 \%$ \\
\hline & Count & $20_{\mathrm{a}}$ & $0_{\mathrm{b}}$ & 20 \\
\hline Tertiary & $\begin{array}{c}\% \text { within Highest Educational } \\
\text { Level of the Father }\end{array}$ & $100.0 \%$ & $0.0 \%$ & $100.0 \%$ \\
\hline & Count & 345 & 160 & 505 \\
\hline Total & $\begin{array}{c}\% \text { within Highest Educational } \\
\text { Level of the Father }\end{array}$ & $68.3 \%$ & $31.7 \%$ & $100.0 \%$ \\
\hline
\end{tabular}

Each subscript letter denotes a subset of Nutritional Status categories whose column proportions do not differ significantly from each other at the 0.05 level.

Table 4. Chi-square tests.

\begin{tabular}{cccc}
\hline & Value & Df & Asymp. Sig. (2-Sided) \\
\hline Pearson Chi-Square & $21.273^{\mathrm{a}}$ & 4 & 0.000 \\
N of Valid Cases & 505 & & \\
\hline
\end{tabular}

a. 0 cells $(.0 \%)$ have expected count less than 5 . The minimum expected count is 6.34 .

respect to higher educational level, most education 345 (68.3\%) out of 505 are undernourished and only 160 (31.7\%) are nourished.

Table 4 shows the Pearson chi-square test which is used to test the relationship association between nutritional status and occupation as predictor variable. Chi-square ( $\chi^{2}=21.273, P=0.000, P<0.005$ ) show to be significant among the educational levels.

\section{Discussion}

From the result of this study, the proportion of male children attending clinics for treatment of aliments and accessing nutritional services only slightly differs from females $(51.5 \%$ vs $48.5 \%)$ (Figure 1). Similar sample characteristics of $53.6 \%$ and $46.4 \%$ for males and females respectively [18]. The percentage of children who have their fathers alive are $81 \%$ (Figure 2) and those with mothers alive 
are $89 \%$ (Figure 3 ). This shows that more children with mothers are slightly higher than those with fathers alive. The results however show that majority of fathers are farmers constituting about $51.5 \%$ in the area studied, followed by those with fathers having no occupation, constituting 21.8\% (Figure 4). Other finding also reported that majority of Kano residents are farmers and merchants [19].

The study also shows that majority of fathers have primary education as the highest educational level, accounting for $46.53 \%$ followed by those with secondary school, $24.75 \%$. This shows that majority of the fathers could not get the opportunity to further their education after completion of primary education, but venture into economic activities such as farming. Only 3.9\% are opportune to proceed to tertiary institution. The school attendance of the sampled children is very low as only $26.7 \%$ are attending schools. This may not be unconnected with the fact that in rural communities, children are often not enrolled into school before attaining the age of 5 years.

The prevalence of malnutrition in the studied area is as high as $68 \%$, despite the fact that majority of the children have fathers alive (81\%) and mothers alive $(89 \%)$ and that $51.5 \%$ of their fathers are farmers. This prevalence obtained in this study is far from what was reported by National Nutrition and Health Survey, 2015 [8]. Severe acute malnutrition (SAM) prevalence for under-five children is reported at 7.2 and 1.8 percent respectively, whereas the same indicators were reported at 8.7 and 2.2 percent in National Nutrition and Health Survey (NNHS) 2015 [8]. In addition, none of the states surveyed that year reported GAM and SAM above critical WHO cut off points, and there has also been a slight reduction in the underweight indicator (19.4 percent compared to 21 percent in 2014). Stunting, however, is still the largest burden, thus indicating a long-term nutritional problem in the country. The indicator is quite stable (33 percent), confirming an overall prevalence positively below Sub-Saharan regional level (37 percent) [8].

However, the frequency of children assessed falling sick is that $30.69 \%$ fell sick at least twice a year. This may not be unconnected with the high prevalence of malnutrition found among the children. Even though it has long been recognized that malnutrition is associated with mortality among children [20] [21], a formal assessment of the impact of malnutrition as a risk factor was only recently carried out. In the early 1990s, results of the first epidemiological study on malnutrition showed that malnutrition potentiated the effects of infectious diseases on child mortality at population level [22].

A multitude of factors lead to malnutrition. These include not having enough money to buy sufficient nutritious food and not having a reliable supply of food throughout the year; gender inequality; poor infant and young child feeding practices; and limited access to healthcare, safe drinking water and adequate sanitation [9]. Lack of purchasing power reduces a household's ability to buy the food it needs, which combined with the other causes mentioned above increases 
the likelihood of malnutrition [9]. Malnutrition can create and perpetuate poverty, which triggers a cycle that hampers economic and social development, and contributes to unsustainable resource use and environmental degradation [23].

In view of the above, the fathers' occupation, which is a function of and purchasing power, was studied in relation to the nutritional status of their children. Children born to petty traders are worse affected as the prevalence among them is as high as $80 \%$, followed by commercial motorcyclists and government workers. This may be attributed by the fact that majority rarely stay with their families as they often on business tours outside the state, mostly in the southern part of the country. Findings also suggest that children born to farmers are significantly affected by undernutrition as $69.2 \%$ of the children with fathers' occupation as farming are undernourished. Ironically, children whose fathers are beggars have $0 \%$ prevalence of undernutrition. This finding suggests that farmers are less likely to feed their children than the beggars. It is common practice in northern rural communities that farm produce are not adequately made availability to families, but rather taken to markets for sale. Additionally, the farmers predominantly produce less nutritionally valuable food for children such as maize, millet and corns. Protein rich food are inadequately produced and livestock rarely slaughtered and eaten. Socioeconomic inequalities in childhood malnutrition are more pronounced in urban centers than in rural areas [24].

In $47 \%$ of surveyed households in Daura LGA, agriculture production was found to account for less than $25 \%$ of the total household food consumption. The remainder of poor household's diet comes largely from buying food in local markets and food received for work. The poor own few livestock and survive through a combination of smallholder agriculture, casual labour and petty trade [9].

Parents' education status is one of the most important determinants of malnutrition [25]. Educated parents are more likely to employ better child-care practices as compared to uneducated parents. According to a study done in Bangladesh, children of mothers with secondary or higher education were at a lower risk of childhood stunting (risk ratio (RR): 0.86), underweight (RR: 0.83) and wasting (RR: 0.82) as compared to children of uneducated mothers [26]. However, findings of this study negate the findings of the above researchers as it shows high prevalence of malnutrition among children with parents who attended tertiary institution (100\%), followed by secondary (76\%) than those with parents attended literacy (70.6\%), primary (63.8\%) and not attended any (50\%). It's however worthy of note that this is a hospital based study and that educated families are more readily attending clinics than the less educated ones.

\section{Conclusion}

There is high prevalence of malnutrition among children in rural communities which is often underestimated for the fact that rural dwellers of Kano are mostly farmers and that they are adequate to provide for their children. Frequency of 
illnesses among the children of rural dwellers is associated with the nutritional status of the children. Malnutrition is not always dependent on the occupation and educational status of the parents or whether child parents are alive or not. Children of farmers and learned persons are also very susceptible to malnutrition in the rural communities of Kano.

\section{Recommendations}

Based on this study, it is recommended that nutritional education in both rural and urban communities should be directed at not only the poor parents, but of particular importance to the educated, wealthy and farmers whose children appeared to be worse affected by undernutrition. Programs in rural communities should rather than focusing on the provision of Ready to Use Therapeutic Foods, concentrate on enlightening caregivers on the use of the locally available farm produce to enhance the nutritional status of their children.

It is also recommended that another study be conducted with sample children drawn from within the communities to cover those malnourished children whose parents have no faith in modern health care.

\section{References}

[1] Aruna, S. and Sudha, P. (2015) A Survey: Malnutrition for Women. International Journal on Computer Science and Engineering, 7, 75-77.

[2] WHO (2017) Global Database on Child Growth and Malnutrition. World Health Organization/Department of Nutrition for Health and Development $\mathrm{CH}$, Geneva. http://www.who.int/nutgrowthdb

[3] World Food Programme (2000) Food and Nutrition Handbook. World Food Programme, Rome.

[4] WHO (2013) Malnutrition-The Global Picture. World Health Organization, Geneva. http://www.who.int/home-page/

[5] Monika, B. and Mercedes, O. (2005) Malnutrition: Quantifying the Health Impact at National and Local Levels: Environmental Burden of Disease Series. World Health Organization, Geneva.

[6] The Food and Agriculture Organization of the United Nations (2011) The State of Food Insecurity in the World: How Does International Price Volatility Affect Domestic Economies and Food Security. FAO, Canada.

[7] Tunji, A., Djurfeldt, G., Holmen, H. and Isinika, A.C. (2005) Conclusions and a Look Ahead. In the African Food Crisis. CABI Publishing, Cambridge.

[8] National Nutrition and Health Survey (NNHS) (2015) http://www.unicef.org/nigeria

[9] Save the Children (2010) Child Malnutrition in Northern Nigeria: Illustrative Case Study. http://www.Savethechildren.org.uk

[10] World Bank (2006) Repositioning Nutrition as Central to Development: A Strategy for Large-Scale Action. World Bank, Washington, DC.

[11] Childers, E. and Urquhart, B. (1994) Renewing the United Nations System. Dag Hammarskjold Foundation, Uppsala, Sweden.

[12] Bain, L.E., Awah, P.K., Geraldine, N., Kindong, N.P., Sigal, Y., Bernard, N. and 
Tanjeko, A.T. (2013) Malnutrition in Sub-Saharan Africa: Burden, Causes and Prospects. Pan African Medical Journal, 15, 120.

https://doi.org/10.11604/pamj.2013.15.120.2535

[13] Olofin, E.A., Nabegu, A.B. and Dambazau, A.M. (2008) Wudil within Kano Region: A Geographical Synthesis. The Department of Geography, Kano University of Science and Technology, Wudil.

[14] Charan, J. and Biswas. T. (2013) How to Calculate Sample Size for Different Study Designs in Medical Research? Indian Journal of Psychological Medicine, 35, 121-126. https://doi.org/10.4103/0253-7176.116232

[15] Ogechi, U.P. (2014) A Study of the Nutritional Status and Dietary Intake of Lactating Women in Umuahia, Nigeria. American Journal of Health Research, 2, 20-26. https://doi.org/10.11648/j.ajhr.20140201.14

[16] Mishra, S.K., Bastola, S.P. and Jha, B. (2009) Biochemical Nutritional Indicators in Children with Protein Energy Malnutrition Attending Kanti Children Hospital, Kathmandu, Nepal. Kathmandu University Medical Journal, 7, 129-134.

[17] WHO and UNICEF (2009) WHO Child Growth Standards and the Identification of Severe Acute Malnutrition in Infants and Children. A Joint Statement by the World Health Organization and the United Nations Children's Fund. http://www.who.int/nutrition/publications/severemalnutrition

[18] Juma, O.A., Enumah, Z.O., Wheatley, H., et al. (2016) Prevalence and Assessment of Malnutrition among Children Attending the Reproductive and Child Health clinic at Bagamoyo District Hospital, Tanzania. BMC Public Health, 16, 1094.

https://doi.org/10.1186/s12889-016-3751-0

[19] Dawaki, S., Al-Mekhlafi, H.M. and Ithol, I. (2016) Is Nigeria Winning the Battle against Malaria? Prevalence, Risk Factors, and KAP Assessment among Hausa Communities in Kano State. Malaria Journal, 15, 351.

https://doi.org/10.1186/s12936-016-1394-3

[20] Trowell, H.C. (1948) Malignant Malnutrition (Kwashiorkor). Transactions of the Royal Society of Tropical Medicine and Hygiene, 42, 417-433. https://doi.org/10.1016/0035-9203(49)90049-8

[21] Gomez, J., et al. (1956) Mortality in Second and Third Degree Malnutrition. The Journal of Tropical Pediatrics, 2, 77-83. https://doi.org/10.1093/oxfordjournals.tropej.a057419

[22] Pelletier, D.L., Frongillo Jr, E.A. and Habicht, J.P. (1993) Epidemiologic Evidence for a Potentiating Effect of Malnutrition on Child Mortality. American Journal of Public Health, 83, 1130-1133. https://doi.org/10.2105/AJPH.83.8.1130

[23] WEHAB (2002) A Framework for Action on Health and the Environment. World Summit on Sustainable Development, Johannesburg, August 2002.

[24] Fotso, J.C. and Kuate-Defo, B. (2005) Household and Community Socioeconomic Influences on Early Childhood Malnutrition in Africa.

http://iussp2005.princeton.edu/papers/50905

[25] Khattak, U.K., Iqbal, S.P. and Ghazanfar, H. (2017) The Role of Parents' Literacy in Malnutrition of Children under the Age of Five Years in a Semi-Urban Community of Pakistan: A Case-Control Study. Cureus, 9, e1316. https://doi.org/10.7759/cureus.1316

[26] Schaible, U.E. and Kaufmann, S.H. (2007) Malnutrition and Infection: Complex Mechanisms and Global Impacts. PLOS Medicine, 4, e115. https://doi.org/10.1371/journal.pmed.0040115 
Submit or recommend next manuscript to OALib Journal and we will provide best service for you:

- Publication frequency: Monthly

- 9 subject areas of science, technology and medicine

- Fair and rigorous peer-review system

- Fast publication process

- Article promotion in various social networking sites (LinkedIn, Facebook, Twitter, etc.)

- Maximum dissemination of your research work

Submit Your Paper Online: Click Here to Submit

Or Contact service@oalib.com 